\title{
Correction: Survival in adults and children with systemic lupus erythematosus: a systematic review and Bayesian meta-analysis of studies from 1950 to 2016
}

Tektonidou MG, Lewandowski LB, Hu J, et al. Survival in adults and children with systemic lupus erythematosus: a systematic review and Bayesian meta-analysis of studies from 1950 to 2016. Ann of Rheum Dis 2017;76:2009-16. doi:10.1136/annrheumdis-2017-211663

The third author's name has been corrected to Jinxiang Hu.

(c) Article author(s) (or their employer(s) unless otherwise stated in the text of the article) 2018. All rights reserved. No commercial use is permitted unless otherwise expressly granted.

Ann Rheum Dis 2018;77:472. doi:10.1136/annrheumdis-2017-211663corr1

Check for updates 